\title{
Children discharged from neonatal intensive care: implications for the social care networks*
}

\author{
Crianças egressas de terapia intensiva neonatal: implicações para as redes sociais de \\ cuidado
}

Maria Licele do Nascimento ${ }^{1}$, Greice Machado Pieszak ${ }^{1}$, Andrea Moreira Arrué2 ${ }^{2}$, Sandra Ost Rodrigues Martins Carvalho $^{1}$

Objective: to understand the social care networks of children discharged from Neonatal Intensive Care Unit. Methods: qualitative study conducted in the home of six families of seven children. In data collection, authors used the triangulation of techniques with thematic content analysis. Results: family composition is nuclear, social networks are formed by the support of family, leisure and spiritual ties, by school and hospital institutions. The families reported the challenges of caring for a premature baby, and the main care demands were respiratory, motor and cognitive. The non-effective communication between professionals and family showed negative impact on hospitalization and home care. Conclusion: social care networks for children discharged from the Neonatal Intensive Care unit proved to be disjointed and health care for children and family proved to be fragmented.

Descriptors: Pediatric Nursing; Children's Health; Family Health; Neonatal Intensive Care Units.

Objetivo: compreender as redes sociais de cuidado de crianças egressas de Terapia Intensiva Neonatal. Métodos: estudo qualitativo, realizado no domicílio de seis famílias de sete crianças. Na coleta de dados, utilizou-se a triangulação de técnicas, com análise de conteúdo temática. Resultados: a composição familiar é nuclear, as redes sociais são formadas pelo apoio dos vínculos familiares, de lazer e espiritual, pelas instituições escolar e hospitalar. As famílias relataram os desafios de cuidar de uma criança prematura, e as principais demandas de cuidado foram respiratórias, motoras e cognitivas. A comunicação não efetiva entre profissionais e família mostrou repercussões negativas na internação e no cuidado domiciliar. Conclusão: as redes sociais de cuidados das crianças egressas de Terapia Intensiva Neonatal mostraram-se desarticuladas e a atenção em saúde à criança e família fragmentada.

Descritores: Enfermagem Pediátrica; Saúde da Criança; Saúde da Família; Unidades de Terapia Intensiva Neonatal.

\footnotetext{
*Extracted from the Work of Conclusion "Crianças egressas de Unidade de Terapia Intensiva Neonatal: implicações para o cuidado familiar e de enfermagem", Universidade Regional Integrada do Alto Uruguai e das Missões - Campus de Santiago, 2015.

${ }^{1}$ Universidade Regional Integrada do Alto Uruguai e das Missões. Santiago, RS, Brazil.

${ }^{2}$ Escola Nacional de Saúde Pública Sérgio Arouca. Manguinhos, RJ, Brazil.

Corresponding author: Maria Licele do Nascimento

Rua Bento Gonçalves, 1823, Apto 31, Centro. CEP: 97700-000. Santiago, RS, Brazil. E-mail: marialicele@gmail.com
} 


\section{Introduction}

Infant mortality rate has had a significant drop in recent decades in Brazil, reflecting actions and programs implemented by the federal government, such as expansion of prenatal care coverage, access to health services, improving living conditions, among others. Globally, child mortality has dropped by more than half in the last 25 years. In Brazil, this reduction was $73.0 \%{ }^{(1)}$. However, the goal of ensuring the right to life and health for all Brazilian children has not yet been achieved due to regional and social inequalities ${ }^{(2)}$.

Infant mortality is seen as an important indicator of living and health conditions of the population as well as the socioeconomic development level. This indicator can provide information on the quality of care provided in prenatal care to pregnant women and newborn ${ }^{(3)}$. Thus, it is important to improve the care for this population, as care for the mother and newborn should pervade the Family Health Strategy through comprehensive actions aimed at monitoring the families. In this context, Neonatology was established as a subspecialty of pediatrics and has a direct impact on the survival of these children ${ }^{(4)}$.

It is known that in the hospital procedures and care are provided by qualified health professionals. However, after discharge, the care required by the child start to be developed by the family at home ${ }^{(5)}$. In this field, there is highlight for Nursing, whose essence and specificity are care for the human being in a comprehensive and holistic manner, and for the nurse's role as an educator and knowledge coordinator.

The families of newborns discharged from the intensive care unit face constant pilgrimages in search of specialized care and require a network of multidisciplinary care able to contribute to their empowerment process. Thus, care networks consist in care actions in the health-disease process. These networks are individualized and defined by size, density and composition, allowing the development of various functions, ranging from social campaigns to emotional support in order to provide the necessary support that serves as a cognitive and advice guide ${ }^{(6)}$.

In this context, nurses and other health professionals should be aware of the child and family needs. The nursing team has an important role in the development of educational activities to help families to adapt to this new situation so as to make them aware of the care provided and of the process of promotion and restoration of health and quality of life $\mathrm{e}^{(7)}$.

Living at home with the child discharged from the Neonatal Intensive Care Unit is experienced as a process of adaptation of the parents and it is during the hospitalization period that the possibility of developing specific skills and knowledge for home care $\operatorname{arises}^{(8)}$. For this purpose, caregiving parents need to receive support from the team to provide care safely and confidently.

The interdisciplinary team, together with the family, can promote new logic in the work of health staff in order to foster care from the perspective of comprehensiveness, so that family members are involved in the process to value autonomy, feelings and needs facing the aid in the care for the mother and the baby ${ }^{(9)}$.

In this sense, authors aimed to understand the social care networks of children discharged from the Neonatal Intensive Care Unit.

\section{Methods}

This is a qualitative study conducted in the home of children from families belonging to Family Health Strategy units in the municipality of Santiago, RS, Brazil, from August to November 2015. The qualitative method allows unveiling social processes still little known pertaining to particular groups, and allows the construction of new approaches, review and creation of new concepts and categories during the investigation ${ }^{(10)}$.

Study participants were six families of seven children discharged from the Neonatal Intensive 
Care Unit from 2012 to 2014, belonging to four Family Health Strategies of the municipality. The data collection was carried out through triangulation of techniques. First, there was the documentary research in epidemiology sector of the city, which allowed the survey of the children's identification data. From this, researchers settled as the inclusion criterion children discharged from Neonatal Intensive Care Unit from 2012 to 2014. The choice of this period was due to the fact that the Epidemiology sector of the Health Department had made available only the data registered in this period. The exclusion criteria were children who died, moved to another the city in this period, and whose registration documents were incomplete and made impossible the contact with the family of this child.

It is noteworthy that the families were contacted through telephone and addresses. After the invitation, the research objectives and the methodology were presented, so that families have the freedom of choice in participation. Of the nineteen children enrolled in the files provided by the epidemiology sector (first data collection technique), thirteen were excluded, of which: three were due to neonatal deaths, four due to change of address, four were not located in their residences (after four attempts to home visits without success), and one family did not agree to participate. Finally, six families participated of the study in a total of seven children, as one of the families had twin children and both had been admitted to the Neonatal Intensive Care Unit.

Authors chose to perform home visits aiming at inclusion in the family scope and because it enables close look at the reality of these members. This strategy provided an opportunity to create bond and trust in the family, as well as interaction between researcher and participants and also the effective applicability of the interview.

Interviews (second data collection technique) were held in the home of each family and had an average duration of ninety minutes each; they were all recorded and transcribed verbatim by the researcher. The questions were conducted through guiding questions; the most important ones were: how was it experiencing the hospitalization of a child in a Neonatal Intensive Care Unit? How did you face this step? And how as was to perform the first care at home? Which were the difficulties and facilities found?

At the end of the interview, it was proposed to families the construction of the genogram and eco-map, (third data collection technique). Such instruments are useful to delineate the internal and external structures of the family. The genogram is a family diagram and the ecomap, on the other hand, is a diagram portraying the contact of the family with other individuals outside the immediate family. Together, they represent important links between the family and the world. These instruments were developed as evaluation, planning and family intervention devices $^{(11)}$.

The data were analyzed by content analysis ${ }^{(10)}$, which consists of three stages: pre-analysis, material exploration, treatment and interpretation of results. The pre-analysis deals with the selection of the documents that will be analyzed and determines the record unit, the context unit, the clippings, the categorization, the coding mode and the theoretical criteria. The material exploration is a classification to reach the meaning core of the text; it investigates the categories that are meaningful words or expressions. And the third step is made up of the results and interpretation $^{(10)}$. To ensure the anonymity of the participants, they were identified by the letter F, representing the word "Family" and the order of the interviews, such as F1, F2, F3.

The study complied with the formal requirements contained in the national and international regulatory standards for research involving human beings.

\section{Results}

From the results obtained, the data were 
ordered into three categories: Characterization of families of children discharged from the Neonatal Intensive Care Unit, Challenges of caring for a child discharged from the Neonatal Intensive Care Unit in the perception of the caregiving family and Display of the social network of children discharged from the Neonatal Intensive Care Unit through the genogram and eco-map.

\section{Characterization of families of children discharged from the Neonatal Intensive Care Unit}

The characterization of participant families showed that the composition was mainly nuclear (father, mother, one to three children); however, in two of these families, the grandmothers of the children lived in the same house. The data relating to birth revealed that gestational age ranged from 29 to 40 weeks, birth weight from $1.400 \mathrm{~g}$ to $3.900 \mathrm{~g}$ and the length of stay from 10 to 43 days. These children are currently aged one year and nine months to three years and ten months; five were male and two were female; four had brothers in the family. With regard to religion, four families were Catholic and two Evangelical, and with regard to the marital status of parents, four were married and two lived in stable union. In addition, the main care demands reported by families were respiratory conditions, deficits in motor and cognitive development.

\section{Challenges of caring for a child discharged from the Neonatal Intensive Care Unit in the perception of the caregiving family}

In this category, the main results showed that the difficulties faced by the family in care for the child after hospital discharge were the identification of the child's fragility due to the immaturity of systems. It was also found that the guidelines acquired during hospital stay and hospital discharge interfered in the conduction of childcare in the home routine. It is the first time that we were experiencing that and everything was made very carefully, because in his first month at home, he had to stay inside a closed room; that was the pediatrician's recommendation (F2Child's mother). It was difficult because he was very tiny and fragile; they guided me not to let people hold him a lot, because he was very small and still had very little weight (F1- Child's mother).

Mothers reported that they faced challenging situations in the child's hospitalization process in the Neonatal Intensive Care Unit, as the anguish of waiting for hospital discharge, in addition to fear that some problem occurs with the child at home. Then, on that day (hospital discharge), it seemed a lie, you know. Because I always arrived at the hospital with that will to come home with my daughter, because it seemed that with the other mothers it was faster, they arrived there and could already go. And my turn never came. Then, it was our day and we took all our bags there for the hospital; it was a great joy! (F5- Child's mother). I was too scared to sleep and something happens to him at home and I did not see. It was my fear. So far, you know, when he has respiratory crises, I even sleep, but I sleep with that fear, a fear of sleeping and, God forbid, he cannot call us (F3- Child's mother).

The results also showed that families faced the fear of loss of the premature child, besides doubts on their survival. Thus, it was evident that communication by the health professional can interfere with family expectations about children's health. He was transferred, but the doctor did not give us any hope. He said, "He will be transferred today, only because it's the right thing to do." Then, he had two arrests on the trip. There (at the hospital), the doctor also told us that, in that case, he would live 24 hours at most. Then they made an application of surfactant and thank God he went beyond those 24 hours. Then they gave another dose until he reached 48 hours, then we got there and he had had a relapse. The physician there (hospital) said we could not go home because he could die any time. His little sister stayed in the (hospital), but only to gain weight (F6- Child's mother). But he got sick and a doctor told me: "This little boy will not survive until nine o'clock at night.". Then I said, but Jesus will give me strength and he will not die. I will never forget it (F3 - Child's grandmother).

The findings of this study showed that the confidence felt by the mother to perform home care was acquired during the period in which the parents were in the Neonatal Intensive Care Unit and were instructed on how to provide care at home. It was 
evidenced by the speeches that health professionals guided the family on child care during hospitalization in the Neonatal Intensive Care Unit; parents revealed trust in the physicians and nurses' role was limited to conducting the lectures. The first care was provided when I went there (hospital); that was when I learned to take care of her. Because there was a room where we stayed with other mothers all together and with them (babies), then, from time to time one of them (professional nursing) would give us guidelines to teach us to care for them (F5- Child's mother). We received guidance by the physicians. We asked them when we had any questions because we trusted them, and it was them who guided us more about first aid and home care (F3 - Child's mother).

In the primary care setting, continuity of care is shown weakened with respect to guidance and care in monitoring the child after hospital discharge. Families sought emergence care as a gateway into the health system. I only go to the health unit to vaccinate him (son) because the doctor does not meet child here. Once I went there (health unit) with him (son) and the doctor said he did not meet children. The health unit team only comes in contact with us to know about us, but they do not offer any service (F1- Child's mother). I take him (son) to the pediatrician, or if I do not manage to schedule a visit, then I take him straight to the emergency room. There, in the emergency room, I have already taken him many times (F4- Child's mother). Then, after a while, I realized that if I take him to the emergency room, I could get a consultation and they would also solve his problem (child) at that time. Now we always take him to the emergency room (F5- Child's mother).

Mothers identified themselves as the main caregiver of the child, explaining they are the most present people in daily care. But they reported that relied on the help of other family members, such as spouse, the child's maternal grandmother and aunts. I take care, but my mother and my father support me a lot, and my sister, whenever I needed, she has helped me, and my sister, she has helped us a lot, both in the birth of my second son and of this son (F2Child's mother). I am the main caregiver, and my mother, because my husband is a truck driver, so he gets very little at home (F6- Child's mother).

It was noted the importance of connection between people and services so that the child has better life and leisure conditions. The school and the family were present and showed to be an important support network for children, as evidenced in the lines: Well, going out, we do not get out much, we only come here (maternal grandmother's house). It is mostly in the daycare, he is now going to kindergarten (F3-Child's mother). She has gone to the daycare since two years old but we had to change the school because we have moved house, so she is returning to the daycare again (F5Child's mother). They go to school in the morning shift, since they were four months old because I used to work, and they love to go to kindergarten (F6- Child's mother).

\section{Display of the social network of children dischar- ged from the Neonatal Intensive Care Unit through the genogram and eco-map}

In this category, researchers chose two genograms and eco-maps to show the main support networks of children discharged from the Neonatal Intensive Care Unit.

In the first figure there is the genogram and eco-map of family (F1), which evidences a fragile and restricted social network.

The first figure also shows that the child's care network was only the hospital, whereas the ideal would be that the family was supported by primary health care. In addition, as a support network, there was the establishment of ties only through contact with maternal grandparents.

In the second figure, the genogram and the ecomap belong to the family (F6), which presented an expanded health care network.

The second figure shows the support of the pediatrician, who develops monthly care in the maternal and child center of the studied city, representing the specialized care and the child education school. In addition, leisure ties are expanded, represented by trips to the parks of the city, to grandparents' house, friends' house and living in the countryside. 


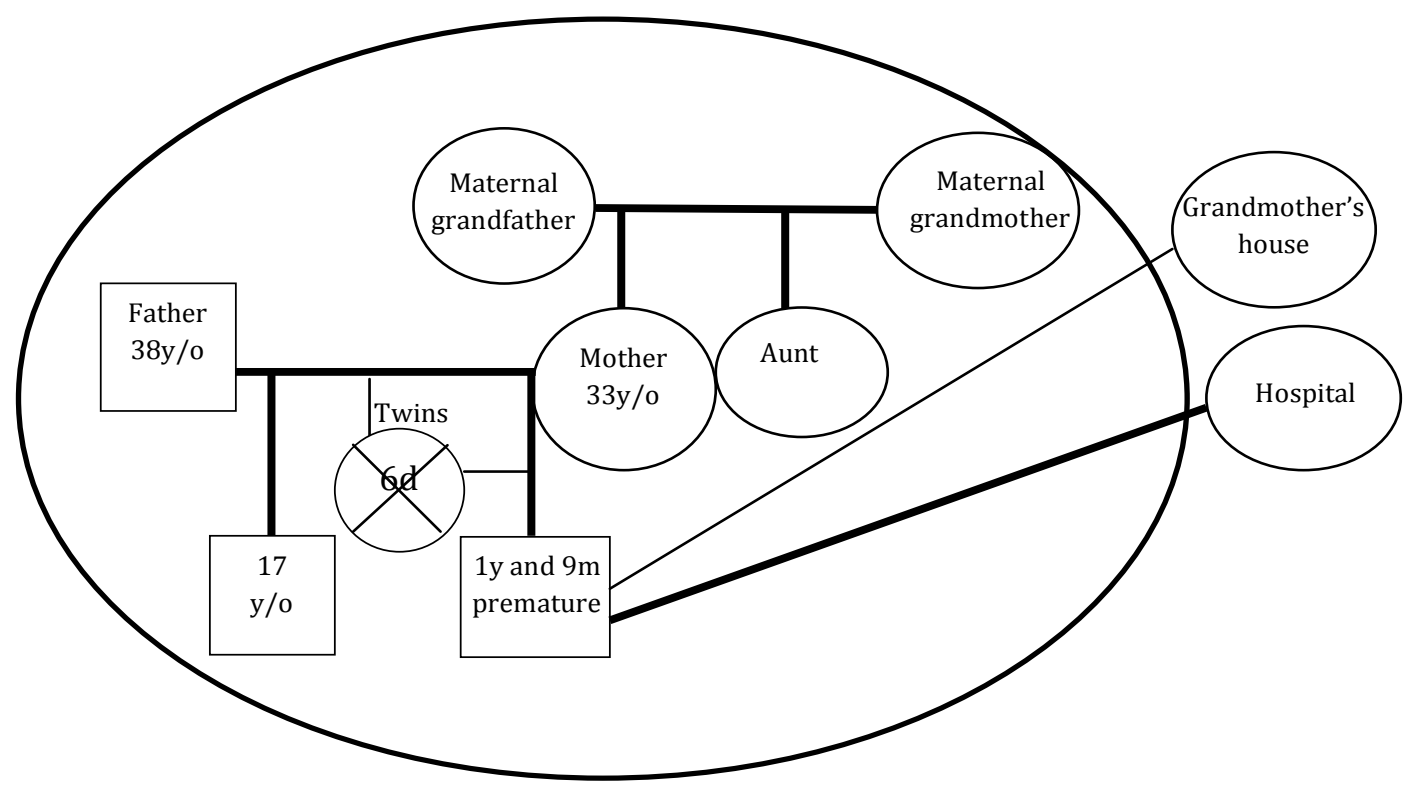

Figure 1 - Genogram and eco-map of family 1

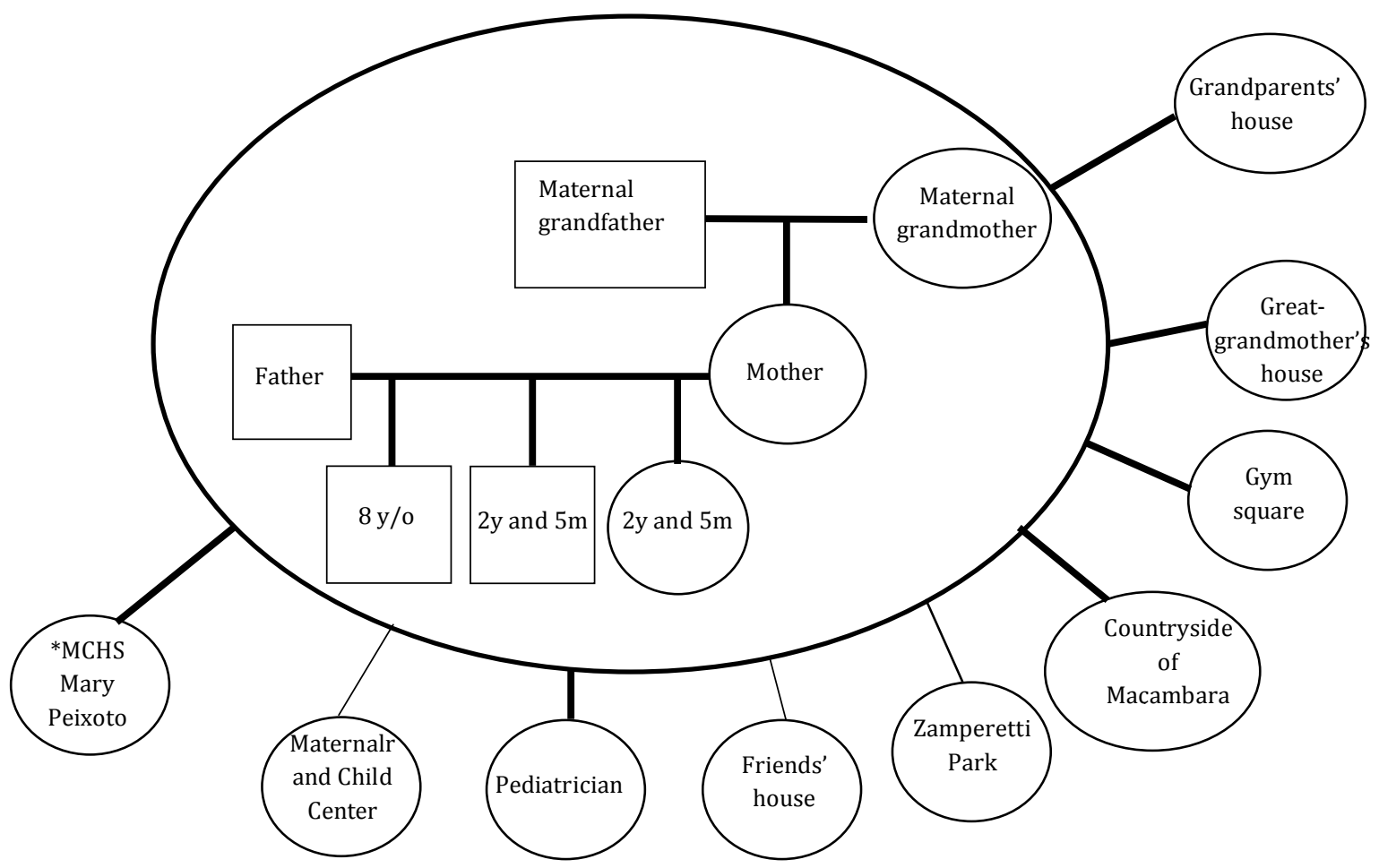

Figure 2 - Genogram and eco-map of family 6 *MCES: Municipal Child Education School 


\begin{tabular}{|c|c|c|}
\hline Strong ties & Marriage symbol \\
\hline Weak ties & & Female \\
\hline Male & & Symbol representing death \\
\hline
\end{tabular}

Figure 3 - Legends of Genogram and eco-map of families 1 and 6

\section{Discussion}

It was possible to understand that the social network of newborns discharged from the Neonatal Intensive Care Unit was basically made up by hospital care, which makes it challenging for the family the continuity of care at home. The health care was fragmented and gave rise to concerns about the resoluteness of the reference and counter-reference system, which hindered access to a set of integrated and coordinated actions in the network.

The characterization of families showed that the main demand of care to children discharged from the Neonatal Intensive Care Unit was respiratory and the reason for admission was due to prematurity and respiratory distress. Data from a survey of children discharged from the Neonatal Intensive Care Unit corroborates the findings of this study, as it shows that the main reasons for hospitalization are prematurity (53.3\%), respiratory distress $(50.5 \%)$ and neonatal infection $(12.8 \%)^{(3)}$.

The results of this study showed that some mothers reported feeling anxiety about waiting for hospital discharge, and fear of losing the premature child. Thus, another study stated that the separation imposed by the hospitalization of the newborn in a Neonatal Intensive Care Unit is painful for the mother and for the baby. Guilt and anxiety are characteristic feelings of parents who remain apprehensive about the child's survival and normality ${ }^{(12)}$.

The dynamics of preparing the mother for the care of the premature child in the Neonatal Intensive
Care Unit must be favored by the performance of nursing professionals through health education activities; this needs to be conveyed to the family horizontally, through dialogue and sensitive listening. Thus, demonstrating and guiding care in a continuous, planned and gradual manner offers to the mother and the family the chance and the time to adapt to the conditions of preterm child during their hospital stay in the neonatal unit ${ }^{(8)}$.

In this context, it becomes clear that the initial adjustments for the adaptation of families as for child care require greater change in their daily lives and intense involvement, especially of the mother ${ }^{(13)}$. Fear of loss demonstrates the fear of mothers in living with the uncertainty of life and death of their newborn children, however, over time, mothers realize that their babies can overcome difficulties ${ }^{(4)}$.

Also, another important result found was fear and lack of confidence of caregiving families about the home care to the child. Therefore, it is evidenced the importance of family and professional network to meet the mother and the child in a comprehensive and humanized manner in order to enable that thee hospital stay in the Neonatal Intensive Care Unit is a preparation for home care after discharge ${ }^{(4)}$.

In this sense, after hospital discharge, it is necessary that the team guides families about the continuity of care in primary health care to ensure monitoring and the child's recovery. Supporting this process is one of the duties of the nurse and the 
Family Health Strategy team at the hospital level. It is the nurse's responsibility to promote the continuity of hospital care at home, in a comprehensive and committed assistance ${ }^{(14)}$.

It was also possible to identify that mothers were the primary caregivers of children and that they received support from grandmothers and sisters. This shows the importance of family support so that this period becomes a time for learning and strengthening of ties. Another study also showed the same result, however, there were different people participating in the care, as the father, because women have greater participation in the formal and informal labor market $^{(13)}$.

In relation to school, this proved to be an important support network for child care since mothers, after a time, needed to return to work, which led them to seek school as care support to children. Thus, it is known that the school becomes important context of socialization and that it is mainly responsible for the transmission of organized knowledge, which is product of cultural development ${ }^{(12)}$. For this reason, it is necessary to pay attention to how the child develops in their schooling and their cognitive development. Also, the primary care team and school professionals need to be interconnected for the proper monitoring of the child.

Social networking is understood as the sum of all the relationships that the individual perceives as significant or different from the anonymous mass of society. These relationships define who is a family member and who is not. Therefore, it is necessary that health professionals look at families and social support networks to expand actions and daily care practices, targeting children's healthy development and compatible with the social and economic reality in which these families live $\mathrm{e}^{(15)}$.

\section{Conclusion}

The results showed the challenges of caring for a premature baby discharged from a Neonatal Intensive Care Unit, the perception of the fragility of children and physiological immaturity at the time of hospital discharge, which generates fear and insecurity in the realization of care. The non-effective communication between professionals and family showed negative impact on hospital and home care. In addition, researchers did not see the work of nurses in health education activities.

The main care demands were respiratory problems and deficits in motor and cognitive development. It was found that family structure was nuclear, and that social networks were formed by the support of family, leisure and spiritual ties, as well as the child education school and care at the tertiary level. Social networks proved to be disjointed, and health care for child and family was fragmented, indicating that the gateway is the emergency child care.

\section{Collaborations}

Nascimento ML and Pieszak GM contributed to the conception and design of the project, collection and analysis of data and writing of the article. Arrué AM and Carvalho SORM contributed in the writing, critical review of the intellectual content of the article and approval of the final version to be published.

\section{References}

1. Word Health Organizacion. Levels \& trends in child mortality [Internet]. 2015 [cited 2015 Oct. 20]. Available from: http://www.unicef.org/ publications/files/Child_Mortality_Report_2015_ Web_8_Sept_15.pdf 
2. Ministério da Saúde (BR). Atenção à Saúde do Recém-Nascido. Guia para os profissionais de saúde. Brasília: Ministério da Saúde; 2012.

3. Tadielo BZ, Neves ET, Arrué AM, Silveira A, Ribeiro AC, Tronco CS, et al. Morbidade e mortalidade de recém-nascidos em tratamento intensivo neonatal no sul do brasil. Rev Soc Bras Enferm Ped. 2013; 13(1):7-12.

4. Tronco CS, Padoin SMM, Paula CC, Brum CN, Rodrigues AP, Trojahn T. Repercussões da internação do recém-nascido de baixo peso à mãe e sua família: uma revisão integrativa da literatura. Rev Soc Bras Enferm Ped. 2012; 12(2):131-7.

5. Leão DM, Silveira A, Rosa EO, Balk RS, Souza NS, Torres OM. Family home care to the child with chronic diseases: an integrative review. Rev Enferm UFPE on line [Internet] 2014; [cited 2016 Mar. 20]; 8(supl.1):2445-54. Available from: http://www.revista.ufpe.br/revistaenfermagem/ index.php/revista/rt/printerFriendly/5937/0

6. Neves ET, Silveira A, Arrué AM, Pieszak GM, Zamberlan KC, Santos RP. Network of care of children with special health care needs. Texto Contexto Enferm. 2015; 24(2):399-406.

7. Severo VRG, Neves ET, Jantsch LB, Zamberlan KC. Health education with families of children with special health needs: literature review. Rev Enferm UFPE on line [Internet]. 2014 [cited 2016 Mar. 20]; 8 (supl.1):2455-62. Available from: http://www.revista.ufpe.br/revistaenfermagem/ index.php/revista/article/viewArticle/4532
8. Couto FF, Praça NS. Recém-nascido prematuro: suporte materno domiciliar para o cuidado. Rev Bras Enferm. 2012; 65(1):19-26.

9. Dantas MSA, Pontes JF, Assis WD, Collet N. Facilidades e dificuldades da família no cuidado à criança com paralisia cerebral. Rev Gaúcha Enferm. 2012; 33(3):73-80.

10. Minayo MCS. Desafio do conhecimento: pesquisa qualitativa em saúde. São Paulo: Hucitec Abrasco; 2014.

11. Wright LM, Leahey M. Enfermeiras e famílias. Um guia para avaliação e intervenção na família. São Paulo: Roca; 2009.

12. Barroso ML, Pontes AL, Rolim KM. Consequences of prematurity in the establishment of the affective bond between teenage mothers and newborns. Rev Rene. 2015; 16(2):168-75.

13. Nishimoto CLJ, Duarte ED. Family organization for the care of children with chronic conditions, discharged from the neonatal intensive care unit. Texto Contexto Enferm. 2014; 23(2):318-27.

14. Silva RVGO, Ramos FRS. 0 trabalho de enfermagem na alta de crianças hospitalizadas: articulação da atenção hospitalar e básica. Rev Gaúcha Enferm. 2011; 32(2):309-15.

15. Dezoti AP, Alexandre AMC, Tallmann VAB, Maftum MA, Mazza VA. Rede social de apoio ao desenvolvimento infantil segundo a equipe de saúde da família. Esc Anna Nery. 2013; 17(4):721-9. 